\title{
New Aminoporphyrins Bearing Urea Derivative Substituents: Synthesis, Characterization, Antibacterial and Antifungal Activity
}

\author{
Gholamreza Karimipour ${ }^{1 *}$ Saeed Kowkabi ${ }^{1}$ and Asghar Naghiha ${ }^{2}$ \\ ${ }^{I}$ Department of Chemistry; Yasouj University; Yasouj - Iran. ${ }^{2}$ Department of Animal Science; Yasouj University; \\ Yasouj - Iran
}

\begin{abstract}
This work studied the synthesis of 5,10,15-tris(4-aminophenyl)-20-(N,N-dialkyl/diaryl-N-phenylurea) porphyrins $\left(P_{1}-P_{4}\right.$ with alkyl or aryl groups of $\mathrm{Ph}, i \mathrm{Pr}$, Et and Me, respectively) and also the preparation of their manganese (III) and cobalt (II) complexes $(\mathrm{MnP}$ and $\mathrm{CoP})$. The $P_{1}-P_{4}$ ligands were characterized by different spectroscopic techniques ( ${ }^{l} \mathrm{H}$ NMR, FTIR, UV-Vis) and elemental analysis, and metalated with Mn and Co acetate salts. The antibacterial and antifungal activities of these compounds in vitro were investigated by agar-disc diffusion method against Escherichia coli (-), Pseudomonas aeruginosa (-), Staphylococcus aureus (+), Bacillus subtilis (+) and Aspergillus oryzae and Candida albicans. Results showed that antibacterial and antifungal activity of the test samples increased with increase of their concentrations and the highest activity was obtained when the concentration of porphyrin compounds was $100 \mu \mathrm{g} / \mathrm{mL}$. The activity for the porphyrin ligands depended on the nature of the urea derivative substituents and increased in the order $P_{1}>P_{2}>P_{3}>P_{4}$, which was consistent with the order of their liposolubility. MnP and CoP complexes exhibited much higher antibacterial and antifungal activity than $P_{1}-P_{4}$ ligands. Further, the growth inhibitory effects of these compounds was generally in the order $\mathrm{CoP}$ complexes $>\mathrm{MnP}$ complexes $>\mathrm{P}_{1}-\mathrm{P}_{4}$ ligands. Among these porphyrin compounds, $\mathrm{CoP}_{1}$ displayed the highest antibacterial and antifungal activity, especially with a concentration of $100 \mu \mathrm{g} / \mathrm{mL}$, against all the four tested bacteria and two fungi, and therefore it could be potential to be used as drug.
\end{abstract}

Key words: Porphyrin, Aminoporphyrins, Antibacterial/Antifungal Activity, Synthesis, Carbamoyl Chloride

\section{INTRODUCTION}

Antibiotic resistance is one of the most severe public health problems globally that is of serious concern. It affects children and adults who have common infections, once easily treatable with antibiotics. It is important to find alternate treatments for microbial infections. Porphyrins and their metallo-derivatives are significant biomimetic compounds that are used in the studies in the areas of chemistry, biology and biotechnology (Banfi et al. 2006; Orlandi et al. 2012, 2013; Dosselli et al. 2013; Katsunori et al.
2013). In the recent years, porphyrins have been studied as flexible model compounds. It is possible to obtain useful biologically active materials by changing the peripheral functional groups in porphyrin skeleton and central metal atom in porphyrin core (Li et al. 1997; Beirão et al. 2014; Prasanth et al. 2014; Meng et al. 2015; Zoltan et al. 2015). Their properties can be tuned for specific application by metalation and/or by introducing substituents selectively at their $\beta$ or meso-position (Goodrich et al. 2013; Nowak-Król and Gryko 2013). Porphyrins with only one, two, or more substituents present a compact

*Author for correspondence: ghkar@yu.ac.ir 
architecture that suites a wide variety of applications, or further synthetic elaboration. To synthesize porphyrins bearing a molecular recognition site, porphyrin synthons that have functional groups at the p-positions of the mesophenyl groups are usually employed, since these functional groups might be further modified by chemical treatments to enhance selectivity in the porphyrin-mediated reactions.

Following interest in development of porphyrins as selective electrodes (Karimipour et al. 2012) and as biomimetic oxidation catalysts (Mohajer et al. 2004; Karimipour et al. 2007, 2013), this work aimed to study the synthesis and characterization of new conjugates of aminoporphyrins in which one urea derivatives joins porphyrin by using carbamoyl chlorides. Also, the corresponding cobalt (II) and manganese (III) porphyrin derivatives were prepared. Finally, the biological activity of the newly synthesized porphyrin ligands and their complexes was tested against antibiotic-resistant fungi (Aspergillus oryzae and Candida albicans) and some Gram (+) and Gram (-) bacteria (Escherichia coli, Pseudomonas aeruginosa, Staphylococcus aureus and Bacillus subtilis).

\section{MATERIAL AND METHODS}

All chemicals and solvents used for this work were obtained from Merck and Fluka Companies. All solvents and pyrrole were used after distillation. The melting points of the synthesized compounds were determined in open-glass capillaries on AKRUSS-KSP1D melting point apparatus. IR absorption spectra were recorded on JASCO-680 using $\mathrm{KBr}$ pellets. UV-Vis spectroscopy was performed using JASCO-570 spectrometer, and ${ }^{1} \mathrm{H}$ NMR spectra were recorded on a BRUKER spectrometer operating at $400 \mathrm{MHz}$. The ${ }^{1} \mathrm{H}$ NMR chemical shifts are reported as parts per million (ppm) downfield from TMS $\left(\mathrm{Me}_{4} \mathrm{Si}\right)$ used as an internal standard. The elemental analysis was performed using an ELEMENTAR series elemental analyzer equipped with a vario EL software (vario EL cube) supplement based on absorption technique with TCD detector.

\section{Synthesis of $N, N$-diphenyl and diisopropylcarbamoyl chloride}

In a $50 \mathrm{~mL}$ two-necked flask, containing triphosgene (3.6 g, $12 \mathrm{mmol})$ in benzene/xylene
(20 $\mathrm{mL}, \quad 1: 1, \quad \mathrm{v} / \mathrm{v}), \quad$ diphenylamine/ diisopropylamine $(39 \mathrm{mmol})$ was added slowly. The reaction was carried out in the presence of dry solid sodium hydroxide as mild catalyst $(600 \mathrm{mg}$, $15 \mathrm{mmol}$ ) for $30 \mathrm{~min}$ under refluxing condition. The reaction mixture was cooled at room temperature and filtered. The filtrate was evaporated in vacuo to dryness and the residue was washed with hot hexane to remove unreacted triphosgene; the mixture was filtered and the resulting residue was crystallized from hexane to give corresponding carbamoyl chloride (Scheme 2; a and b) (Zare et al. 2012).

Diphenylcarbamoyl chloride (grey-green crystalline powder, yield: $73 \%$ ), mp: $84{ }^{\circ} \mathrm{C}$, IR $\left(\mathrm{KBr}, v, \mathrm{~cm}^{-1}\right): 760(\mathrm{C}-\mathrm{Cl}), 1350(\mathrm{C}-\mathrm{N}), 1650$ $(\mathrm{C}=\mathrm{O}), \quad 3050 \quad(\mathrm{C}-\mathrm{H}$ aromatic) and diisopropylcarbamoyl chloride (white to yellow solid, yield: $68 \%)$, mp: $58{ }^{\circ} \mathrm{C}$, IR $\left(\mathrm{KBr}, \mathrm{v}, \mathrm{cm}^{-1}\right)$ : $760(\mathrm{C}-\mathrm{Cl}), 1400(\mathrm{C}-\mathrm{N}), 1680(\mathrm{C}=\mathrm{O}), 3050(\mathrm{C}-\mathrm{H}$ $\left.\mathrm{sp}^{3}\right)$.

Synthesis of $N, N$-dimethyl and diethylcarbamoyl chloride

In a $50 \mathrm{~mL}$ two-necked flask, containing triphosgene $(4.5 \mathrm{~g}, 15 \mathrm{mmol})$ in benzene/xylene $(15 \mathrm{~mL}, 1: 1, \mathrm{v} / \mathrm{v}), 40 \%$ aqueous dimethylamine solution/diethylamine $(49 \mathrm{mmol})$ was added dropwise. The reaction was stirred and refluxed in the presence of dry solid sodium hydroxide as mild catalyst $(750 \mathrm{mg}, 19 \mathrm{mmol}$ ) for $30 \mathrm{~min}$ to give corresponding carbamoyl chloride (Scheme 2, c and d) (Zare et al. 2012).

Dimethylcarbamoyl chloride (yellow liquid with a pungent odor, yield: $56 \%$ ), bp: $167{ }^{\circ} \mathrm{C}$, IR (KBr, $v$, $\left.\mathrm{cm}^{-1}\right): 680(\mathrm{C}-\mathrm{Cl}), 1400(\mathrm{C}-\mathrm{N}), 1500(\mathrm{C}=\mathrm{O}), 3000$ $\left(\mathrm{C}-\mathrm{H} \mathrm{sp}^{3}\right)$. Diethylcarbamoyl chloride (clear to slightly grayish liquid, yield: $61 \%$ ), bp: $122{ }^{\circ} \mathrm{C}$, IR $\left(\mathrm{KBr}, \mathrm{v}, \mathrm{cm}^{-1}\right): 675(\mathrm{C}-\mathrm{Cl}), 1400(\mathrm{C}-\mathrm{N}), 1500$ $(\mathrm{C}=\mathrm{O}), 3050\left(\mathrm{C}-\mathrm{H} \mathrm{sp}^{3}\right)$.

\section{Synthesis of $\quad 5,10,15,20$-tetrakis(4- nitrophenylporphyrin); $\mathrm{H}_{2} \mathrm{~T}\left(4-\mathrm{NO}_{2} \mathrm{PP}\right)$}

$\mathrm{H}_{2} \mathrm{~T}\left(4-\mathrm{NO}_{2} \mathrm{PP}\right)$ was prepared according to a previously reported method (Adler et al. 1967). A mixture of 4-nitrobenzaldehyde $(11 \mathrm{~g}, 73 \mathrm{mmol})$ and acetic anhydride $(12 \mathrm{~mL}, 127 \mathrm{mmol})$ in distilled propionic acid $(300 \mathrm{~mL})$ was refluxed for $5 \mathrm{~min}$. Freshly distilled pyrrole $(5 \mathrm{~mL}, 72 \mathrm{mmol}$ ) was then added and progress of the reaction was monitored by TLC and UV-Vis spectroscopy. After completion of the reaction $(12 \mathrm{~h})$, the solution was cooled and the black heavy 
precipitate was collected by filtration, washed by deionized water and dried. The crude material was taken into pyridine $(80 \mathrm{~mL})$, and the reaction mixture was then refluxed for $2 \mathrm{~h}$. The mixture was kept in refrigerator at $0^{\circ} \mathrm{C}$ for $24 \mathrm{~h}$, and then filtered and dried under ambient condition. $\mathrm{H}_{2} \mathrm{~T}(4-$ $\left.\mathrm{NO}_{2} \mathrm{PP}\right) \quad(\sim 20 \%)$ was characterized by spectroscopic techniques. UV-Vis $\left(\lambda_{\max } \mathrm{nm}\right.$ in $\mathrm{CH}_{2} \mathrm{Cl}_{2}$ at $\left.298^{\circ} \mathrm{K}\right),\left[\log \varepsilon\left(10^{3} \mathrm{M}^{-1} \mathrm{~cm}^{-1}\right]\right.$ : (Soret) 425 [208], (Q-IV) 517 [15], (Q-III) 552 [8], (Q-II) 591 [6], (Q-I) 657 [4]. IR $\left(\mathrm{KBr}, v, \mathrm{~cm}^{-1}\right), 3318$ (pyrrole $\mathrm{NH}$ ), 1591 (aromatic $\mathrm{C}=\mathrm{C}$ ), 1513 (aromatic $\mathrm{NO}_{2}$ ), 1336 (aromatic $\mathrm{NO}_{2}$ ), 1102 (aromatic $\mathrm{C}-\mathrm{H}$ inplane bend). ${ }^{1} \mathrm{H}$ NMR $\left(\mathrm{CDCl}_{3}\right):-2.95(\mathrm{~s}, 2 \mathrm{H}$, pyrrole $\mathrm{NH}), 8.82(\mathrm{~s}, 8 \mathrm{H}, \beta$-pyrrole $), 8.66(\mathrm{~d}, 8 \mathrm{H}, \mathrm{J}$ $=8.6 \mathrm{~Hz}, 2,6-(4-n i t r o p h e n y l)), 8.40(\mathrm{~d}, 8 \mathrm{H}, \mathrm{J}=8.4$ $\mathrm{Hz}, 3,5$-(4-nitrophenyl)).

\section{Synthesis of $5,10,15,20$-tetrakis(4- aminophenylporphyrin); $\mathrm{H}_{2} \mathrm{~T}\left(4-\mathrm{NH}_{2} \mathrm{PP}\right)$}

$\mathrm{H}_{2} \mathrm{~T}\left(4-\mathrm{NH}_{2} \mathrm{PP}\right)$ was prepared by the reduction of $\mathrm{H}_{2} \mathrm{~T}\left(4-\mathrm{NO}_{2} \mathrm{PP}\right)$ with $\mathrm{SnCl}_{2} \cdot 2 \mathrm{H}_{2} \mathrm{O}$ and concentrated hydrochloric acid (Chen and Hsieh 1997). In a 100 $\mathrm{mL}$ three-necked flask, $\mathrm{H}_{2} \mathrm{~T}\left(4-\mathrm{NO}_{2} \mathrm{PP}\right)(1.7 \mathrm{~g}, 2.1$ $\mathrm{mmol}$ ) was dissolved in concentrated hydrochloric acid $(20 \mathrm{~mL}, 37 \%)$ and the resulting green mixture was vigorously stirred at room temperature for $1 \mathrm{~h}$. Simultaneously, in a two-necked $100 \mathrm{~mL}$ flask, a solution containing stannous chloride dihydrate $(1.1 \mathrm{~g}, 4.88 \mathrm{mmol})$ and concentrated hydrochloric acid $(30 \mathrm{~mL}, 37 \%)$ was prepared with stirring by performing argon atmosphere for $1 \mathrm{~h}$. Then, this solution was quickly added to the mixture containing $\mathrm{H}_{2} \mathrm{~T}\left(4-\mathrm{NO}_{2} \mathrm{PP}\right)$, by pipette and the reaction was refluxed at $75-80{ }^{\circ} \mathrm{C}$ for $2 \mathrm{~h}$. After completion of the reaction, ammonium hydroxide (25\%) was added dropwise until the neutral $\mathrm{pH}$. Then, it was kept under chemical hood for $24 \mathrm{~h}$, filtered and dried. The dark green product was dissolved in $100 \mathrm{~mL} \mathrm{NaOH}$ solution (5\%) and stirred for $30 \mathrm{~min}$. Again the solution was filtered and washed several times with distilled water and dried. The powder residue placed in a cellulose extraction thimble and final purification was performed by use of Soxhlet extraction apparatus in the presence of chloroform $(250 \mathrm{~mL})$ for $72 \mathrm{~h}$. After the purification was completed, the solvent was evaporated and the purple residue was pulverized to a fine powder (scheme 3 ). $\mathrm{H}_{2} \mathrm{~T}(4-$ $\left.\mathrm{NH}_{2} \mathrm{PP}\right) \quad(\sim 80 \%)$ was characterized by spectroscopic techniques. UV-Vis $\left(\lambda_{\max } \mathrm{nm}\right.$ in $\mathrm{CH}_{2} \mathrm{Cl}_{2}$ at $\left.298^{\circ} \mathrm{K}\right),\left[\log \varepsilon\left(10^{3} \mathrm{M}^{-1} \mathrm{~cm}^{-1}\right]\right.$ : (Soret) 428 [257], (Q-IV) 522 [12], (Q-III) 562 [12], (Q-II)
596 [6], (Q-I) 654 [5]. IR $\left(\mathrm{KBr}, v, \mathrm{~cm}^{-1}\right), 3322$ (pyrrole and amine $\mathrm{NH}$ ), 1598 (aromatic $\mathrm{C}=\mathrm{C}$ ), 3348 (asy $\mathrm{NH}_{2}$ ), 3360 (sy $\mathrm{NH}_{2}$ ), 1180 (aromatic C$\mathrm{H}$ in-plane bend), 741 (aromatic $\mathrm{C}-\mathrm{H}$ out-of-plane bend). ${ }^{1} \mathrm{H}$ NMR $\left(\mathrm{CDCl}_{3}\right): \delta-2.73(\mathrm{~s}, 2 \mathrm{H}$, pyrrole $\mathrm{NH}), 4.06\left(\mathrm{~s}, 8 \mathrm{H}\right.$, amine $\left.\mathrm{NH}_{2}\right), 8.90(\mathrm{~s}, 8 \mathrm{H}, \beta-$ pyrrole), $7.99(\mathrm{~d}, 8 \mathrm{H}, \quad \mathrm{J}=8.1 \mathrm{~Hz}, 2,6-(4-$ aminophenyl)), 7.07 (d, 8H, J = 8.1 Hz, 3,5-(4aminophenyl)).

\section{Synthesis of 5,10,15-tris(4-aminophenyl)-20- ( $N, N$-dialkyl/diaryl- $N$-phenylurea) porphyrins} $\mathrm{H}_{2} \mathrm{~T}\left(4-\mathrm{NH}_{2} \mathrm{PP}\right)(679 \mathrm{mg}, 1 \mathrm{mmol})$ was added to dry THF $(150 \mathrm{~mL})$ and the reaction flask was transferred into an ice-water bath. After dissolving the porphyrin, triethylamine $(300 \mathrm{mg}, 2.99 \mathrm{mmol})$ was added as $\mathrm{HCl}$ scavenger to the reaction mixture. Then, dialkyl/diarylcarbamoyl chloride (1 mmol) solution in dry THF $(25 \mathrm{~mL})$ was added dropwise over $30 \mathrm{~min}$ and the reaction mixture was vigorously stirred in ice-water bath for $3 \mathrm{~h}$. Finally, the precipitate was filtered and washed thoroughly with ethanol and hot water to extract $\mathrm{Et}_{3} \mathrm{HN}^{+} \mathrm{Cl}^{-}$salt and obtain compounds $\mathrm{P}_{1}-\mathrm{P}_{4}$ (Scheme 4).

\section{5,10,15-tris(4-aminophenyl)-20-( $N, N$-diphenyl- $N$-phenylurea) porphyrin; $\mathbf{P}_{1}$}

(Yield: $\left.79 \%, \mathrm{mp}>300{ }^{\circ} \mathrm{C}\right) .{ }^{1} \mathrm{H}$ NMR $\left(\mathrm{CDCl}_{3}\right)$ : $-2.67(\mathrm{~s}, 2 \mathrm{H}, \mathrm{NH}), 4.10\left(\mathrm{~s}, 6 \mathrm{H}, \mathrm{NH}_{2}\right), 7.31(\mathrm{~s}, 1 \mathrm{H}$, $\mathrm{NH}$; amide), $8.95\left(\mathrm{~s}, 8 \mathrm{H}_{\beta}\right.$, pyrrole), $8.27\left(\mathrm{~m}, 6 \mathrm{H}_{\mathrm{m}}\right.$, 4-aminophenyl), 8.30 (m, 6H, 4 -aminophenyl), $8.03\left(\mathrm{~m}, 2 \mathrm{H}_{\mathrm{m}}, 4-N, N\right.$-phenyl- $N$-phenylurea), 8.12 (m, $2 \mathrm{H}_{0}, \quad 4-N, N$-phenyl-N-phenylurea). UV-Vis $\left(\lambda_{\max } \mathrm{nm}\right.$ in $\left.\mathrm{CH}_{2} \mathrm{Cl}_{2}\right): 419$ (Soret), 521, 572, and 677. IR $\left(\mathrm{KBr}, v, \mathrm{~cm}^{-1}\right): 1650(\mathrm{C}=\mathrm{O}), 3350\left(\mathrm{NH}_{2}\right.$ amine), $3300(\mathrm{NH}$ amide), $1540(\mathrm{C}=\mathrm{C} \mathrm{Ph})$. EA calcd for $\mathrm{C}_{57} \mathrm{H}_{43} \mathrm{~N}_{9} \mathrm{O}: \mathrm{C}, 78.69 ; \mathrm{H}, 4.98 ; \mathrm{N}, 14.49$; O, 1.84. Found: C, 78.16; H, 5.11; N, 14.35; O, 1.78 .

\section{5,10,15-tris(4-aminophenyl)-20-( $N, N$ -} diisopropyl- $N$-phenylurea) porphyrin; $\mathbf{P}_{2}$ (Yield: $\left.72 \%, \mathrm{mp}>300{ }^{\circ} \mathrm{C}\right) .{ }^{1} \mathrm{H}$ NMR $\left(\mathrm{CDCl}_{3}\right)$ : $2.73(\mathrm{~s}, 2 \mathrm{H}, \mathrm{NH}), 3.35\left(\mathrm{~m}, 6 \mathrm{H}, \mathrm{NH}_{2}\right), 7.83(\mathrm{~s}, 1 \mathrm{H}$, $\mathrm{NH}$; amide), $8.87\left(\mathrm{~s}, 8 \mathrm{H}_{\beta}\right.$, pyrrole $), 6.90\left(\mathrm{~d}, 8 \mathrm{H}_{\mathrm{m}}\right)$, $7.83\left(\mathrm{~d}, 8 \mathrm{H}_{\mathrm{o}}\right), 3.24-3.52\left(\mathrm{~m}, 12 \mathrm{H}, \mathrm{CH}_{3}\right.$ bonded to $\left.\mathrm{CH}_{\mathrm{iPr}}\right), 2.3-2.6\left(\mathrm{~m}, 2 \mathrm{H}, \mathrm{CH}_{\mathrm{iPr}}\right)$. UV-Vis $\left(\lambda_{\max } \mathrm{nm}\right.$ in $\mathrm{CH}_{2} \mathrm{Cl}_{2}$ at $298{ }^{\circ} \mathrm{K}$ ): 423 (Soret), 518, 574, and 678. IR $\left(\mathrm{KBr}, v, \mathrm{~cm}^{-1}\right): 1640(\mathrm{C}=\mathrm{O}), 3360\left(\mathrm{NH}_{2}\right.$ amine), 3300 (NH amide), 3050 (aromatic $\mathrm{C}-\mathrm{H}$ ), 2890 (aliphatic C-H), 1200 (C-N). EA calcd for 
$\mathrm{C}_{51} \mathrm{H}_{47} \mathrm{~N}_{9} \mathrm{O}: \mathrm{C}, 76.38 ; \mathrm{H}, 5.91 ; \mathrm{N}, 15.72, \mathrm{O}, 1.99$. Found: C, 76.85; H, 5.49; N, 15.98; O, 2.11.

\section{5,10,15-tris(4-aminophenyl)-20-( $N, N$-diethyl- $N$ - phenylurea)porphyrin; $\mathbf{P}_{\mathbf{3}}$}

(Yield: $\left.77 \%, \mathrm{mp}>300{ }^{\circ} \mathrm{C}\right) .{ }^{1} \mathrm{H}$ NMR $\left(\mathrm{CDCl}_{3}\right)$ : 2.67 (s, 2H, NH), $4.08\left(\mathrm{~s}, 6 \mathrm{H}, \mathrm{NH}_{2}\right), 8.03(\mathrm{~d}, 1 \mathrm{H}$, $\mathrm{NH}$; amide), $8.93\left(\mathrm{~s}, 8 \mathrm{H}_{\beta}\right.$, pyrrole), $7.10\left(\mathrm{~d}, 8 \mathrm{H}_{\mathrm{m}}\right)$, $7.32\left(\mathrm{~m}, 8 \mathrm{H}_{\mathrm{o}}\right), 3.78\left(\mathrm{t}, 4 \mathrm{H}, \mathrm{CH}_{2}\right.$ (ethyl)), $1.57(\mathrm{~m}$, $6 \mathrm{H}, \mathrm{CH}_{3}$ (ethyl)). UV-Vis $\left(\lambda_{\max } \mathrm{nm}\right.$ in $\mathrm{CH}_{2} \mathrm{Cl}_{2}$ at $\left.298^{\circ} \mathrm{K}\right): 421$ (Soret), 519, 575, and 672. IR (KBr, $\left.v, \mathrm{~cm}^{-1}\right): 1670(\mathrm{C}=\mathrm{O}), 3340\left(\mathrm{NH}_{2}\right.$ amine $), 3300$ (NH amide), 2950 (aromatic C-H), $1200(\mathrm{C}-\mathrm{N})$. EA calcd for $\mathrm{C}_{49} \mathrm{H}_{43} \mathrm{~N}_{9} \mathrm{O}: \mathrm{C}, 76.04 ; \mathrm{H}, 5.60 ; \mathrm{N}$, 16.29, O, 2.07. Found: C, 75.74; H, 5.39; N, $16.34 ; \mathrm{O}, 2.12$.

\section{5,10,15-tris(4-aminophenyl)-20-( $N, N$-dimethyl- $N$-phenylurea) porphyrin; $\mathrm{P}_{\mathbf{4}}$}

(Yield: $\left.74 \%, \mathrm{mp}>300{ }^{\circ} \mathrm{C}\right) .{ }^{1} \mathrm{H}$ NMR $\left(\mathrm{CDCl}_{3}\right)$ : 2.66 (s, 2H, NH), 4.05 (s, 6H, NH $), 8.03(\mathrm{~d}, 1 \mathrm{H}$, $\mathrm{NH}$; amide), $8.93\left(\mathrm{~s}, 8 \mathrm{H}_{\beta}\right.$, pyrrole), $7.10\left(\mathrm{~d}, 8 \mathrm{H}_{\mathrm{m}}\right)$, $7.29\left(\mathrm{~m}, 8 \mathrm{H}_{\mathrm{o}}\right), 1.89\left(\mathrm{~m}, 6 \mathrm{H}\right.$, methyl). UV-Vis $\left(\lambda_{\max }\right.$ $\mathrm{nm}$ in $\mathrm{CH}_{2} \mathrm{Cl}_{2}$ at $298{ }^{\circ} \mathrm{K}$ ): 418 (Soret), 516, 579, and 676. IR $\left(\mathrm{KBr}, v, \mathrm{~cm}^{-1}\right): 1670(\mathrm{C}=\mathrm{O}), 3365$ ( $\mathrm{NH}_{2}$ amine), $3300(\mathrm{NH}$ amide), 1200(C-N). EA calcd for $\mathrm{C}_{47} \mathrm{H}_{39} \mathrm{~N}_{9} \mathrm{O}: \mathrm{C}, 75.68 ; \mathrm{H}, 5.27 ; \mathrm{N}, 16.90$, O, 2.15. Found: C, 76.25; H, 5.41; N, 17.13; O, 1.98 .

\section{Synthesis of $\mathrm{MnP}_{1}-\mathrm{MnP}_{4}$}

$\mathrm{MnP}_{1}-\mathrm{MnP}_{4}$ was prepared using the Adler method by mixing of $\mathrm{P}_{1}-\mathrm{P}_{4}(0.7 \mathrm{mmol})$ and manganese (II) acetate tetrahydrate $(490 \mathrm{mg}, 2.0 \mathrm{mmol})$ in $N, N$ dimethylformamide (DMF) $(100 \mathrm{~mL})$ (Adler et al. 1970). The reaction mixtures were briefly stirred in reflux condition for $2 \mathrm{~h}$ and then cooled at room temperature. The solution was filtered and the precipitate was dissolved in small amount of $\mathrm{CH}_{2} \mathrm{Cl}_{2}$ and purified by silica gel chromatography with $\mathrm{CHCl}_{3} / \mathrm{EtOAc}$ as eluant to obtain $\mathrm{MnP}_{1}-\mathrm{MnP}_{4}$ as green powder (yield $=47-58 \%$ ) $($ Scheme 5 ) and confirmed by electronic spectra. UV-Vis $\left(\lambda_{\max } \mathrm{nm}\right.$ in $\mathrm{CH}_{2} \mathrm{Cl}_{2}$ at $298^{\circ} \mathrm{K}$ ); $\mathrm{MnP}_{1}: 466$ (Soret), 514, 561, $\mathrm{MnP}_{2}: 470$ (Soret), 525, 559, $\mathrm{MnP}_{3}: 475$ (Soret), 520, 559, $\mathrm{MnP}_{4}: 468$ (Soret), 513, 560. These spectroscopic data were similar to data previously reported manganese porphyrin systems (Michael et al. 1984).

\section{Synthesis of $\mathrm{CoP}_{1}-\mathrm{CoP}_{4}$}

Cobalt porphyrins derivatives were synthesized according to Lauher and Ibers (1974). The $\mathrm{P}_{1}-\mathrm{P}_{4}$
(0.65 mmol) was placed in a $250 \mathrm{~mL}$ two-necked round bottom flask and $80 \mathrm{~mL}$ of freshly distilled chloroform was added; the mixture was stirred and heated for $10 \mathrm{~min}$ to dissolve the porphyrin completely. A solution consisting of cobalt (II) acetate tetrahydrate $(2.0 \mathrm{~g}, 8.0 \mathrm{mmol})$ in $50 \mathrm{~mL}$ methanol was added and the mixture was heated to reflux for $2 \mathrm{~h}$. The solution was cooled at room temperature and the reaction mixture added to a separatory funnel containing of $100 \mathrm{~mL}$ of distilled water. The chloroform was placed at the bottom, while the methanol and excess inorganic salt was dissolved in the water. After repeating this operation, most of the inorganic salts and methanol were removed and the chloroform solution of the cobalt porphyrin was washed several times with fresh water. Finally, the chloroform solution was dried over $\mathrm{Na}_{2} \mathrm{SO}_{4}$, the drying agent was filtered off, and then the filtrate was evaporated to dryness. The $\mathrm{CoP}_{1}-\mathrm{CoP}_{4}$ was separated as dark-red crystals (yield: 59-83\%) (Scheme 5). UV-Vis $\left(\lambda_{\max } \mathrm{nm}\right.$ in $\mathrm{CH}_{2} \mathrm{Cl}_{2}$ at 298 $\left.{ }^{\circ} \mathrm{K}\right)$; $\mathrm{CoP}_{1}$ : 412 (Soret), 541, 573, $\mathrm{CoP}_{2}$ : 416 (Soret), 545, 583, $\mathrm{CoP}_{3}$ : 415 (Soret), 539, 580, $\mathrm{CoP}_{4}$ : 414 (Soret), 543, 581 (Chizhova et al. 2013).

\section{RESULTS AND DISCUSSION}

\section{Antibacterial and antifungal activity test}

The in vitro antibacterial and antifungal activity test of newly synthesized porphyrin compounds were carried out against E. coli (ATCC 25922), $S$. aureus (ATCC 6538), P. aeruginosa (ATCC 9027), B. subtilis (ATCC 6633), A. oryzae (ATCC 20423) and C. albicans (isolated from a patient). The antibacterial activities were evaluated by the agar-disc diffusion method as per National Committee for Clinical Laboratory Standards guidelines (NCCLS 1997). The filter paper sterilized discs saturated with measured quantity of the sample $(25,50$ and $100 \mu \mathrm{g} / \mathrm{mL})$ were placed on plate containing solid bacterial medium (Muller Hinton agar/broth) and fungal medium (sabouraud dextrose agar). The assay plates were incubated at $25^{\circ} \mathrm{C}$ for $72 \mathrm{~h}$, at $25^{\circ} \mathrm{C}$ for 5 days and at $37^{\circ} \mathrm{C}$ for $24 \mathrm{~h}$ for yeast, fungus and bacteria, respectively. After incubations, the diameters of the clear zone of inhibition surrounding the sample were measured in millimeters by digital caliper (Figs. 16 , vide infra). 
Several reagents such as phosgene (carbonyl dichloride) (Ryan et al. 1996; Marrs et al. 1996; Goren et al. 1991), diphosgene (trichloromethyl chloroformate) (Hood and Murdock 1919; Kurita et al. 1976; Skorna and Ugi 1977) and triphosgene (bis(trichloromethyl) carbonate) (Ramsperger and Waddington 1933; Babad and Zeiler 1973; Nolan et al. 2012) have been used previously for phosgenation. The synthetic applications and characteristics of triphosgene have been reviewed recently. Compared to phosgene and diphosgene, it exhibits superior properties. Generally, aliphatic and aromatic carbamoyl chlorides are prepared from amines and phosgene group compounds by a simple one-step condensation method (Scheme 1) (Tilley and Sayigh 1963; Johnson 1967).

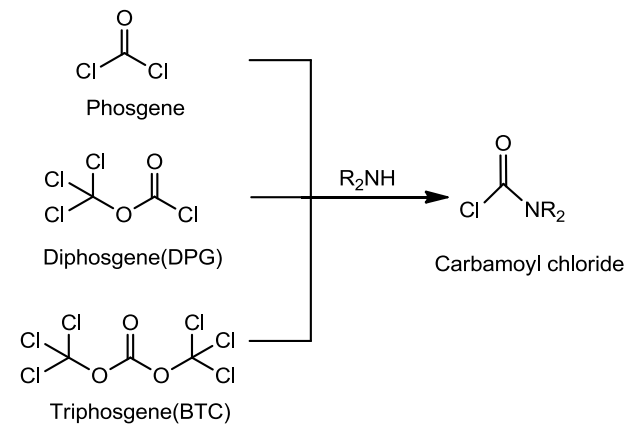

Scheme 1 - Phosgenation reagents and carbamoyl chloride structures.

In this work triphosgene was used for the synthesis of carbamoyl chloride derivatives instead of phosgene and diphosgene to avoid handling hazardous and high risk materials. Carbamoyl chloride is used in the various reactions such as nucleophilic substitution reactions, Grignard reagents (Marcos et al. 2010), amine reactions (Montel et al. 2008), production of urea derivatives (Fish et al. 2008; Gumaste and Deshmukh 2004; Kamisaki et al. 2009), cycloaddition reactions to generate heterocycles (Grzyb and Batey 2008) and also polymerization reactions to produce polymers such as polyurethanes (Hamdach et al. 2006).
In this study, carbamoyl chlorides a-d were prepared by reacting the secondary amines $\left(\mathrm{R}_{2} \mathrm{NH}\right.$; $\mathrm{R}=\mathrm{Ph}, i-\mathrm{Pr}, \mathrm{Et}$ and $\mathrm{Me}$ ) with reagent triphosgene, a stable phosgene substitute (Scheme 2) (Zare et al. 2012).

The reactions were clean and only the carbamoyl chlorides were detected by spectroscopic analysis of the crude products. The produced carbamoyl chlorides had a chloride leaving group that allowed for addition-elimination reactions with amines. This directed us to design a series of nonsymmetrical aminoporphyrins containing urea derivatives using these carbamoyl chlorides.

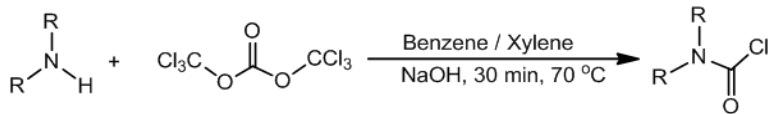

$$
\begin{aligned}
& \text { a) } \mathrm{R}=\mathrm{Ph} \\
& \text { b) } \mathrm{R}=\mathrm{iPr} \\
& \text { c) } R=E t \\
& \text { d) } \mathrm{R}=\mathrm{Me}
\end{aligned}
$$

\section{Synthesis of aminoporphyrins bearing urea derivative substituents and their metal complexes}

As reported previously (Adler et al. 1967), 5,10,15,20-tetrakis(4-nitrophenylporphyrin);

$\mathrm{H}_{2} \mathrm{~T}\left(4-\mathrm{NO}_{2} \mathrm{PP}\right)$ was prepared using freshly distilled 4-nitrobenzaldehyde and pyrrole and identified by UV-Vis spectroscopy. Starting with the prepared $\mathrm{H}_{2} \mathrm{~T}\left(4-\mathrm{NO}_{2} \mathrm{PP}\right)$ and reduction of the $\mathrm{NO}_{2}$ groups with $\mathrm{SnCl}_{2} / \mathrm{HCl}$, it can be obtained 5,10,15,20-tetrakis(4-aminophenylporphyrin); $\mathrm{H}_{2} \mathrm{~T}\left(4-\mathrm{NH}_{2} \mathrm{PP}\right)$, as a potent starting porphyrin wherein each $p$-phenyl positions occupied by amino-groups (Scheme 3) (Chen et al. 1997).

The reaction of $\mathrm{H}_{2} \mathrm{~T}\left(4-\mathrm{NH}_{2} \mathrm{PP}\right)$ with carbamoyl chlorides a-d in a 1:1 molar ratio gave aminoporphyrins $\mathrm{P}_{1}-\mathrm{P}_{4}(72-79 \%)$ in which only one amino group converted into urea derivatives. A typical profile of these reactions is reported in Scheme 4.

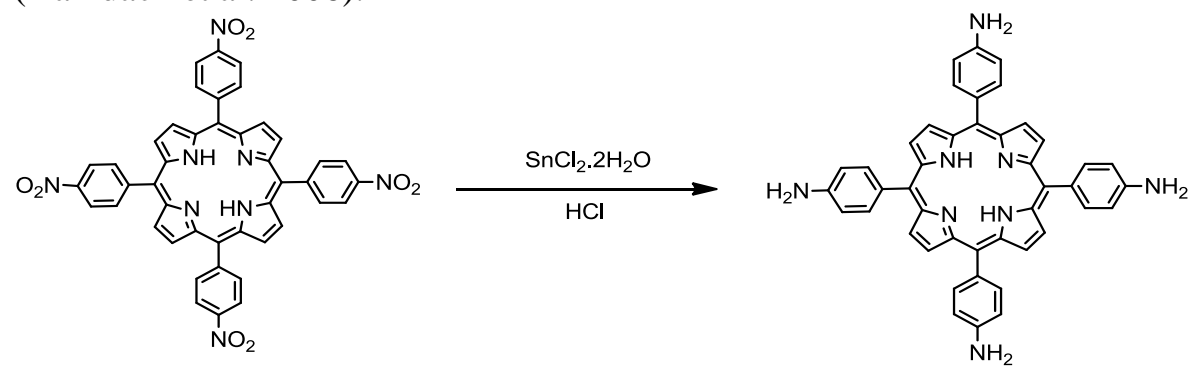

Scheme 3 - Synthesis of 5,10,15,20-tetrakis(4-aminophenylporphyrin). 


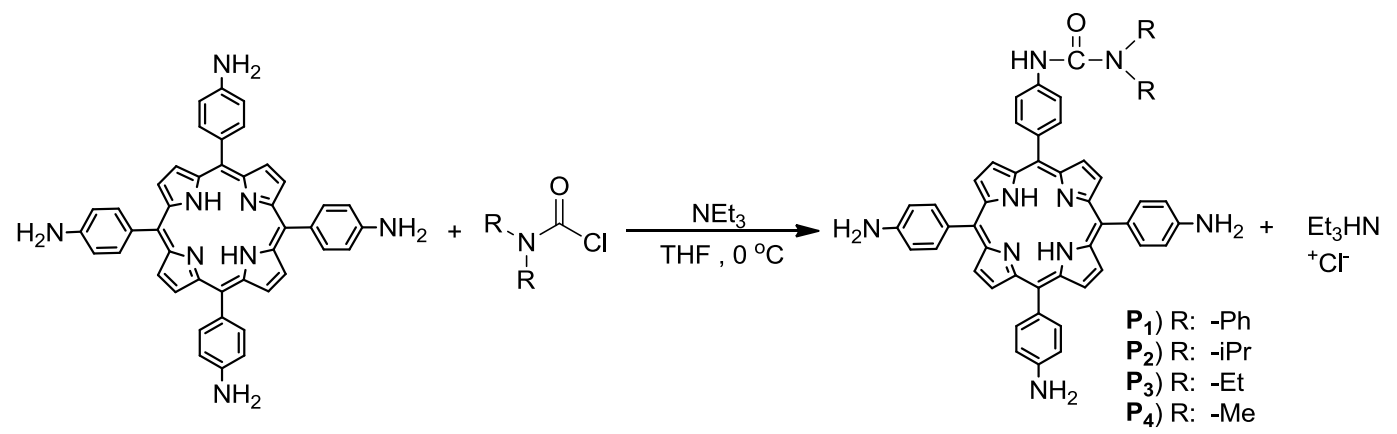

Scheme 4 - Synthesis of 5,10,15-tris(4-aminophenyl)-20-( $N, N$-dialkyl/diaryl- $N$-phenylurea) porphyrins.

Formation of the $\mathrm{P}_{1}-\mathrm{P}_{4}$ was confirmed by the IR, ${ }^{1} \mathrm{H}$ NMR and UV-Vis spectroscopy. The IR spectra of the compounds showed a strong absorption at about $1650 \mathrm{~cm}^{-1}$ due to the carbonyl stretch. In ${ }^{1} \mathrm{H}$ NMR, the pyrrole and phenyl ring protons appeared in 7.29-8.93 ppm and the methyl groups emerged at 1.57-3.52 ppm. The two inner NH signals appeared at $-2.66-(-2.73) \mathrm{ppm}$ as a weak singlet. The signals at about 4 and $8 \mathrm{ppm}$ indicated the free $-\mathrm{NH}_{2}$ and the $-\mathrm{NH}$ of amide substituent, respectively (see Materials and Methods section).

In comparison with $\mathrm{H}_{2} \mathrm{~T}\left(4-\mathrm{NH}_{2} \mathrm{PP}\right)$, the unchanged Soret absorption band of $\mathrm{P}_{1}-\mathrm{P}_{4}$ showed that $N, N$ dialkyl/diarylcarbamoyl chloride reacted selectively only with a peripheral amino group and the key aromatic $18 \mathrm{e}$ structure of the porphyrin skeleton stayed intact. The conversion of $\mathrm{H}_{2} \mathrm{~T}(4-$ $\left.\mathrm{NH}_{2} \mathrm{PP}\right)$ to $\mathrm{P}_{1}-\mathrm{P}_{4}$ was monitored by the IR spectral change. In $\mathrm{P}_{1}-\mathrm{P}_{4}$ compounds, the $-\mathrm{NH}$ amide group stretching vibrations displayed a characteristic band at about $3300 \mathrm{~cm}^{-1}$ rang, while this band did not appear in $\mathrm{H}_{2} \mathrm{~T}\left(4-\mathrm{NH}_{2} \mathrm{PP}\right)$. The $\mathrm{Mn}$ and $\mathrm{Co}$ porphyrin complexes ( $\mathrm{MnP}$ and $\mathrm{CoP}$ ) were synthesized by the reaction of $\mathrm{P}_{1}-\mathrm{P}_{4}$ and the corresponding metal acetate salts (Scheme 5). The formation of porphyrin complexes and bonding modes were inferred from the positions of characteristic bands in UV-Vis spectra (vide supra).

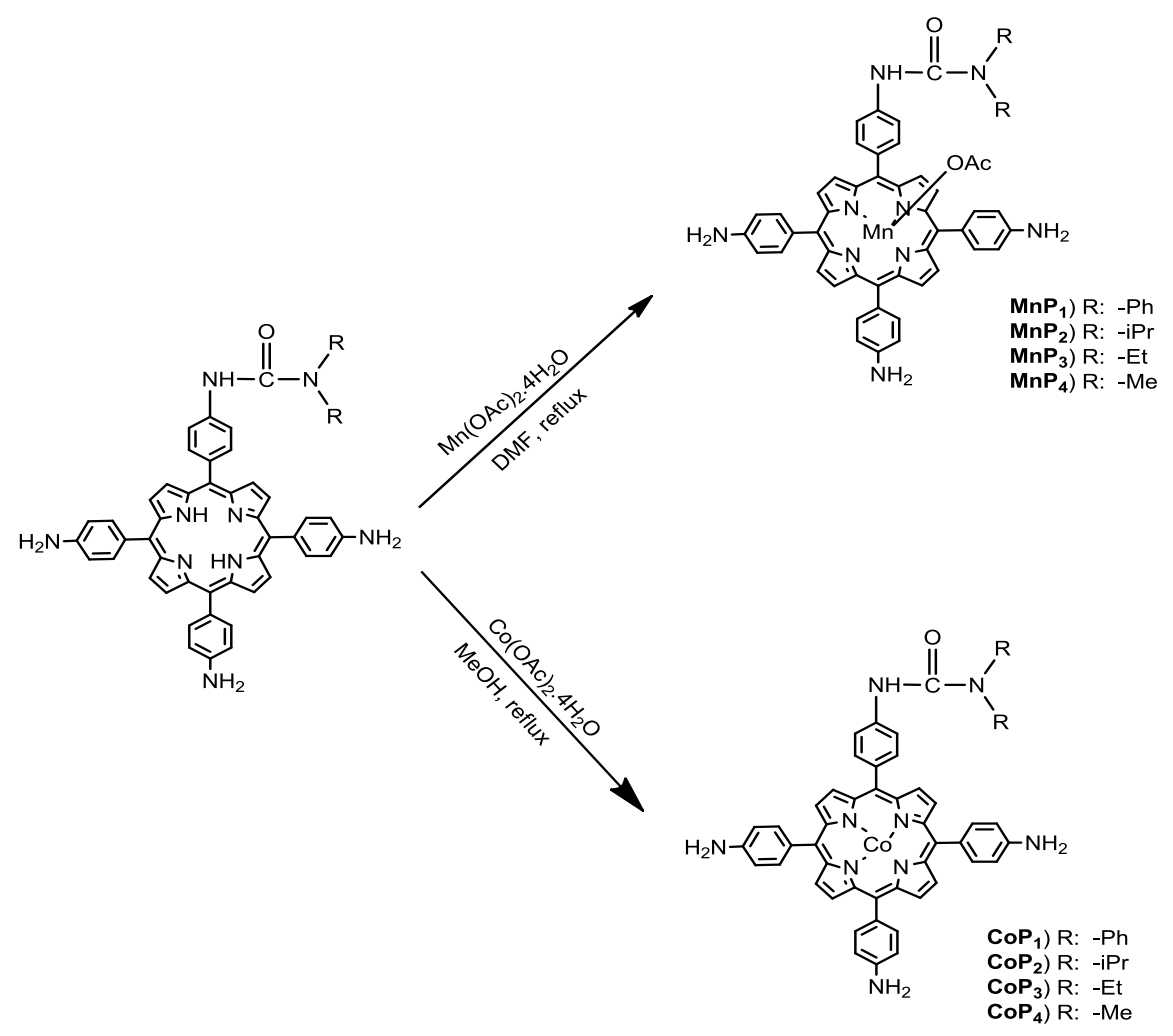

Scheme 5 - Synthesis of manganese and cobalt complexes of $P_{1}-P_{4}$ porphyrin. 
Antibacterial and Antifungal bioassay (in vitro)

Tetrapyrrolic compounds such as porphyrins and their complexes are considered an important class of organic compounds, which have wide applications in many biological aspects (Boulton et al. 2001; Chiller et al. 2001; Maisch et al. 2004; Meisel and Kocher 2005; Satyasheel and Mahendra 2013; Bajju et al. 2014). The biological activity of the porphyrins and their complexes in inhibition of bacterial growth could be attributed to one of the following mechanisms. The first mechanism could be by the inhibition of the bacterial cell wall synthesis by bounding to the precursor of the cell wall, and second mechanism revealed that some antibodies had similar stereo structure to substrate (D-alanyl D-alanine). Hence, it would act competitive inhibitions for the enzymes (transpeptidase and /or carboxpeptidase), which were the main enzymes catalyzed the end step in the biosynthesis of peptidoglycans of the bacterial cell wall. Other mechanisms could contribute to the results found in the study that included the inhibition of biosynthesis of bacterial proteins by linking to the ribosome by doing so. The ribosome would not be in contact with tRNA (transfer ribonucleic acid), hence, the bacteria would not survive. Other mechanisms postulated that some antibodies inhibited the de novo synthesis of bacterial DNA by splitting the DNA in DNA-enzyme complexes by inhibiting DNA ligase (Murray et al. 1991; Baron et al. 1994).

In this study, the antibacterial activity of all new porphyrins and their complexes against the studied bacteria was indicated by the growth free "zone of inhibition" near the respective disc. The sensitive bacteria grew everywhere, except in the areas around the disc containing porphyrin compounds and antibiotic in the medium. The in vitro activity tests were carried out using the growth inhibitory zone (well method) (Indu et al. 2006; Tabatabaeian et al. 2013). The potency of components was determined against the two Gram-negative bacteria (E. coli, and $P$. aeruginosa), two Gram-positive bacteria ( $S$. aureus and B. subtilis) and two fungi (A. oryzae, and C. albicans).

The results reported in Figures 1-3 for bacteria and Figures 4-6 for fungi, and also two samples of the growth inhibition halos are represented in Figure 7. The synthesized compounds showed varying degree of inhibitory effects: low (up to $10 \mathrm{~mm}$ ), moderate (up to $16 \mathrm{~mm}$ ) and significant (above 16 $\mathrm{mm})$. The parent $\mathrm{H}_{2} \mathrm{~T}\left(4-\mathrm{NH}_{2} \mathrm{PP}\right)$ could not be thoroughly investigated due to its very low solubility in DMSO. However, the urea substituents on the porphyrins $\mathrm{P}_{1}-\mathrm{P}_{4}$ ligands and the respective metalloporphyrins increased their solubility in DMSO. $\mathrm{P}_{1}$ possessed a moderate activity against the bacterial strains at $25 \mu \mathrm{g} / \mathrm{mL}$ (Fig. 1) and $50 \mu \mathrm{g} / \mathrm{mL}$ (Fig. 2), but indicated moderate to high activity at $100 \mu \mathrm{g} / \mathrm{mL}$ (Fig. 3). $\mathbf{P}_{2}$ exhibited low activity against all the strains at 25 $\mu \mathrm{g} / \mathrm{mL}$, but it was improved with increasing the concentration, which indicated moderate activity against S. aureus and B. subtilis at 50 and 100 $\mu \mathrm{g} / \mathrm{mL}$. Also, $\mathrm{P}_{3}$ and $\mathrm{P}_{4}$ exhibited weak to moderate activity against these bacterial strains. Hence, both antibacterial and antifungal activities for the ligands increased in the order $\mathrm{P}_{1}>\mathrm{P}_{2}>\mathrm{P}_{3}$ $>\mathrm{P}_{4}$. The observed difference in activity could attribute to the difference in lipophilicity of the porphyrin ligands (vide infra) containing different urea derivative substituents.

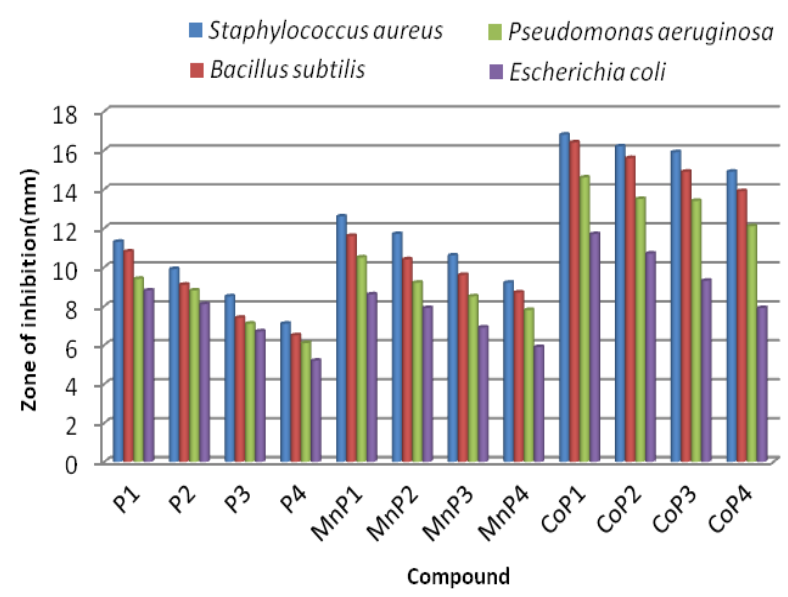

Figure 1 - Antibacterial activity of porphyrins and their complexes $(25 \mu \mathrm{g} / \mathrm{mL})$ by disc-diffusion method.

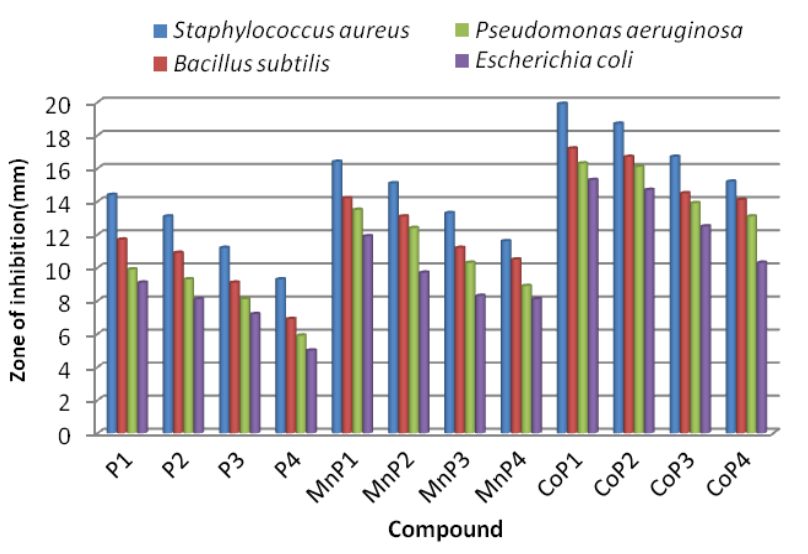

Figure 2 - Antibacterial activity of porphyrins and their complexes $(50 \mu \mathrm{g} / \mathrm{mL})$ by disc-diffusion method. 


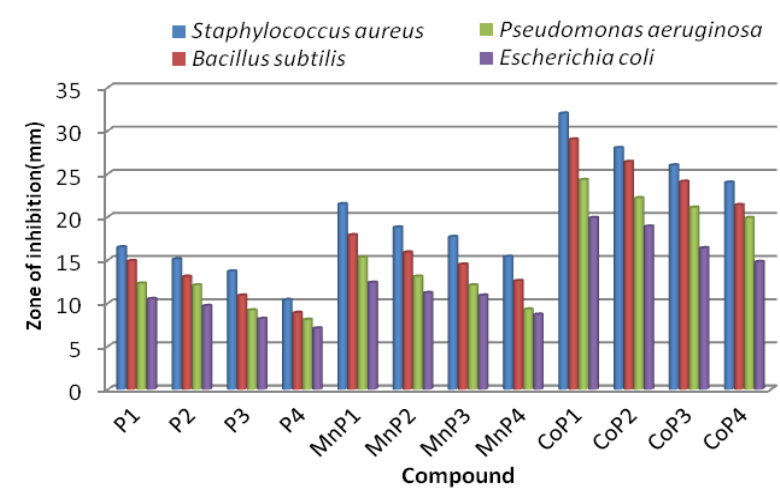

Figure 3 - Antibacterial activity of porphyrins and their complexes $(100 \mu \mathrm{g} / \mathrm{mL})$ by disc-diffusion method.

As the second step, $\mathrm{MnP}_{1}-\mathrm{MnP}_{4}$ complexes were tested for their inhibitory effects on the growth of bacterial strains. $\mathrm{MnP}_{1}$ showed moderate activity against $S$. aureus, B. subtilis and $P$. aeruginosa, but was weak against $E$. coli at $25 \mu \mathrm{g} / \mathrm{mL}$ concentration, whereas significant activity was observed against $S$. aureus and moderate activity against all other bacterial strains at $50 \mu \mathrm{g} / \mathrm{mL}$ for this compound. At higher concentration (100 $\mu \mathrm{g} / \mathrm{mL}), \mathrm{MnP}_{1}$ exhibited significant activity against the four bacterial strains, except E. coli. Similarly, $\mathrm{MnP}_{2}$ showed moderate activity against $S$. aureus and $B$. subtilis at $25 \mu \mathrm{g} / \mathrm{mL}$, whereas with increasing the concentration of $\mathrm{MnP}_{2}$ solution to $100 \mu \mathrm{g} / \mathrm{mL}$, the inhibition diameter was increased. It showed significant activity against $S$. aureus, $B$. subtilis and moderate against $P$. aeruginosa and $E$. coli. The reduction in halo diameters was observed for $\mathrm{MnP}_{3}$ and $\mathrm{MnP}_{4}$ (Figs. 1-3). Hence, antibacterial and antifungal activity for these manganese porphyrins was in the order $\mathrm{MnP}_{1}>$ $\mathrm{MnP}_{2}>\mathrm{MnP}_{3}>\mathrm{MnP}_{4}$.

Finally, a similarly inhibitory effect on the microorganisms as $\mathrm{CoP}_{1}>\mathrm{CoP}_{2}>\mathrm{CoP}_{3}>\mathrm{CoP}_{4}$ was also detected for $\mathrm{Co}$ (II) complexes. The inhibitory effect of $\mathrm{CoP}_{1}$ and $\mathrm{CoP}_{2}$ complexes was investigated, which showed the most antibacterial activity against these bacterial strains. The $\mathrm{CoP}_{1}$ exhibited the highest effect and showed significant activity against $S$. aureus and $B$. subtilis and also moderate against $P$. aeruginosa and $E$. coli even at low concentration $(25 \mu \mathrm{g} / \mathrm{mL})$. This metalloporphyrin had maximum antibacterial against all four bacterial strains between $\mathrm{P}_{1}-\mathrm{P}_{4}$ porphyrins and their synthesized complexes in this study, which showed significant activity against $S$. aureus $(32 \mathrm{~mm}), \quad B$. subtilis $(29 \mathrm{~mm}), \quad P$. aeruginosa $(24.3 \mathrm{~mm})$ and $E$. coli $(19.9 \mathrm{~mm})$ at
$100 \mu \mathrm{g} / \mathrm{mL}$, which were admissible. Similarly, $\mathrm{CoP}_{2}$ exhibited moderate to significant activity, especially at 50 and $100 \mu \mathrm{g} / \mathrm{mL} . \mathrm{CoP}_{3}$ showed significant activity against $S$. aureus at all the three concentrations and moderate against the others and also showed significant activity against the four bacterial strains at $100 \mu \mathrm{g} / \mathrm{mL} . \mathrm{CoP}_{4}$ showed moderate to significant activity against all bacterial strains, except for $E$. coli. The antifungal activities of the porphyrins and their complexes were quantitatively assessed by the presence, or absence of inhibition zones and zone diameters against $C$. albicans and A. oryzae according to Zahid et al. (2010) (Figs. 4-6). These compounds showed remarkable inhibition zones at $100 \mu \mathrm{g} / \mathrm{mL}$. The porphyrins $\mathrm{P}_{1}-\mathrm{P}_{2}$ showed weak antifungal activity but their complexes, especially cobalt derivatives exhibited moderate to significant activity against C. albicans and A. oryzae. Recent studies have indicated that different metals cause discrete and distinct types of injuries to microbial cells as a result of oxidative stress, protein dysfunction or membrane damage (Lemire et al. 2013). The same pattern was obtained and observed in this study. Different antimicrobial activity of $\mathrm{P}_{1}-\mathrm{P}_{4}$ and their complexes suggested different mechanism and/or biocidal property. Further studies are required to explore the exact mechanism of antibacterial and antifungal potency. Overall, the solvent used to prepare the compound solutions (DMSO) did not show inhibition against the tested organisms (negative control), the antibacterial and antifungal activity of free porphyrins $\mathrm{P}_{1}-\mathrm{P}_{4}$ increased upon coordination to metal ions. They inhibited the growth of bacteria and fungi more than the parent uncomplexed ligands under identical experimental conditions (Figs. 1-6).

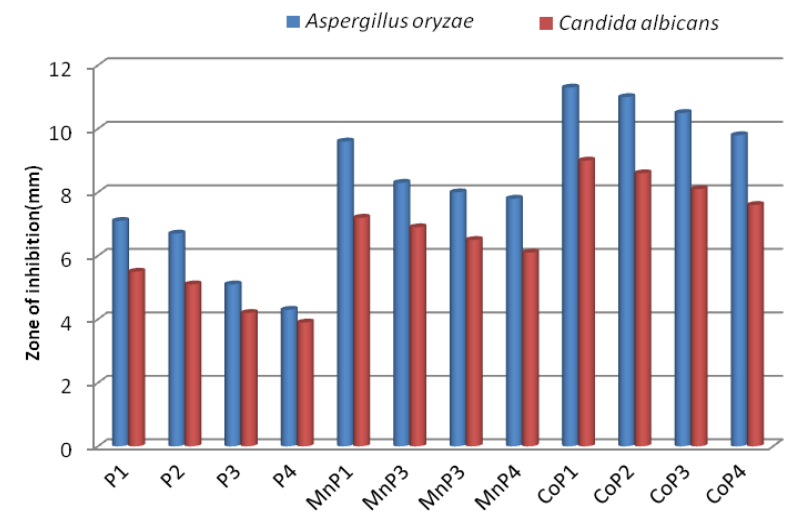

Figure 4 - Antifungal activity of porphyrins and their complexes $(25 \mu \mathrm{g} / \mathrm{mL})$ by disc-diffusion method. 


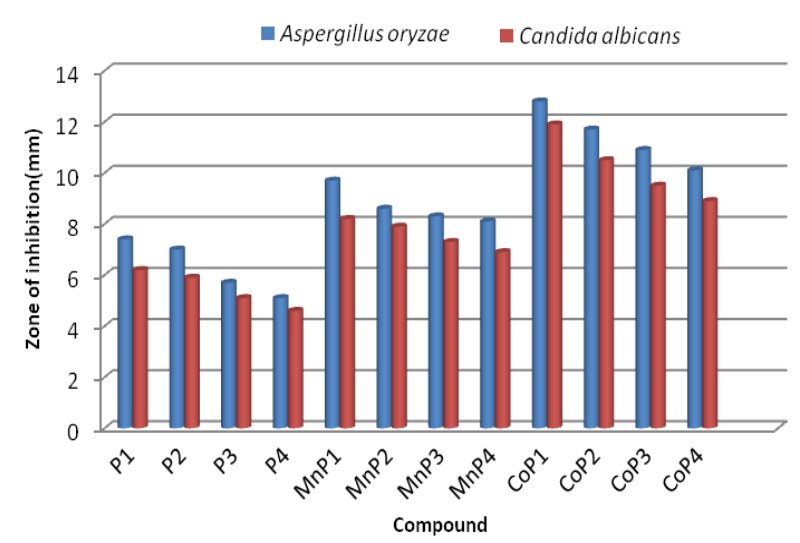

Figure 5 - Antifungal activity of porphyrins and their complexes $(50 \mu \mathrm{g} / \mathrm{mL})$ by disc-diffusion method.

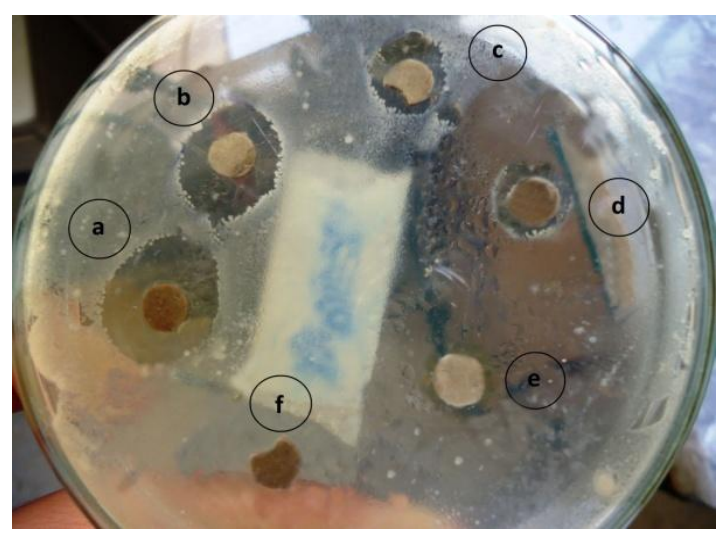

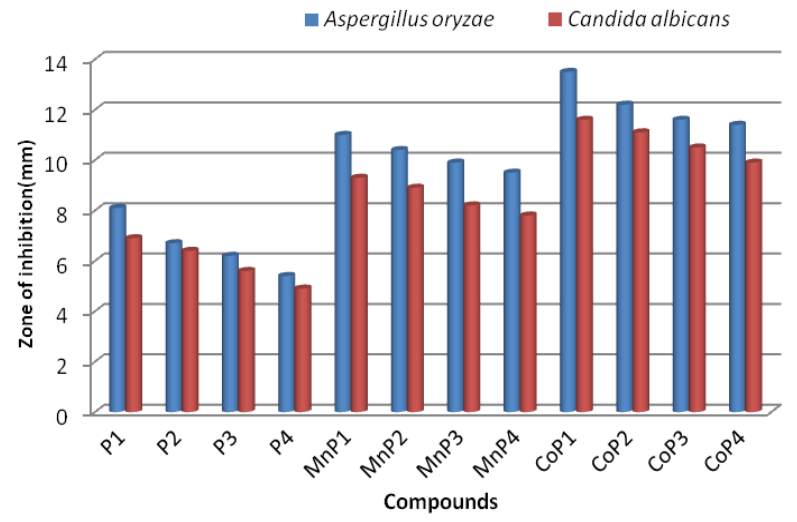

Figure 6 - Antifungal activity of porphyrins and their complexes $(100 \mu \mathrm{g} / \mathrm{mL})$ by disc-diffusion method.

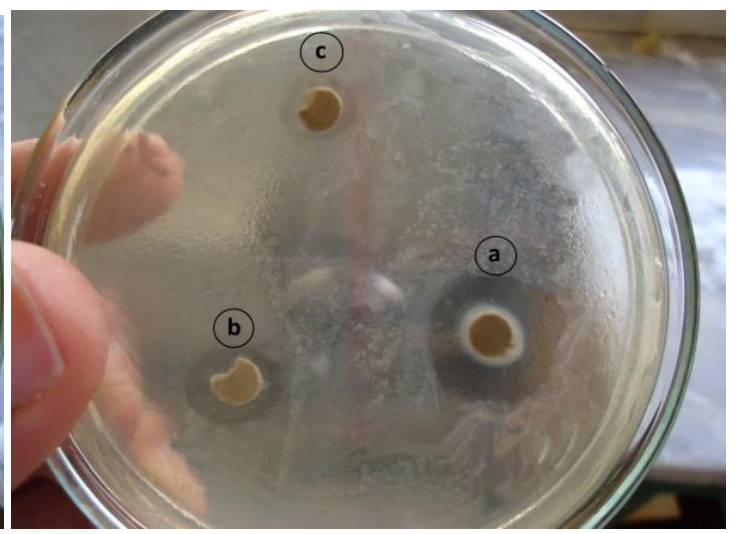

Figure 7 - Zone of inhibition for antimicrobial activity of $\mathrm{CoP}_{1}$ (right pic: (a) S. aureus, (b) B. subtilis and (c) $P$. aeruginosa) and antifungal activity of $\mathrm{CoP}_{1}$ ((left pic: (a) A. oryzae, (b) C. albicans); $\mathrm{CoP}_{2}$ (left pic: (c) A. oryzae, (d) C. albicans) and $\mathrm{CoP}_{3}$ (left pic: (e) A. oryzae (f) C. albicans).

Such increase in the activity of the complexes compared to that of ligands could be explained on the basis of Overtone's concept (Overton 1901) and Tweedy's Chelation theory (Tweedy 1964). According to Overtone's concept of cell permeability, the lipid membrane that surrounds the cell favors the passage of only the lipid-soluble materials, which makes liposolubility as an important factor that controls the antibacterial and antifungal activity. Upon chelation, the polarity of cation is reduced to a greater extent due to the overlap of the ligand orbital and partial sharing of the positive charge of the metal ion. The chelation increases the delocalization of $p$-electrons over the whole chelate ring and enhances the lipophilicity of the complexes. It is plausible that $\mathrm{MnP}$ complexes contain $\mathrm{Mn}^{3+}$ and $\mathrm{P}^{2-}$ and an $\mathrm{OAc}^{-}$as counter ion that makes it less lipophilic and less able to act as antibacterial and antifungal agents. However, in $\mathrm{CoP}$ complexes, $\mathrm{Co}^{2+}$ is almost completely neutralized by the porphyrin ligands $\left(\mathrm{P}^{2-}\right)$. Therefore, the polarity is minimized and the liposolubility of $\mathrm{CoP}$ complexes is significantly increased.

This increase in lipophilicity enhances the penetration of the complexes into lipid membranes, and blocks the metal binding sites of the enzymes of the microorganism. Metal complexes also disturb the respiration process of the cell and, block the synthesis of the proteins and can restrict further growth of the organism. In this study, $\mathrm{MnP}$ and $\mathrm{CoP}$ complexes were more reactive than the corresponding uncomplexed $\mathrm{P}_{1^{-}}$ $\mathrm{P}_{4}$ ligands. Among different porphyrin complexes, $\mathrm{CoP}_{1}$ showed the highest antibacterial and antifungal activity. The literature survey revealed 
that antibacterial and antifungal activity of these 5,10,15-tris(4-aminophenyl)-20-(N,N-dialkyl/ diaryl- $N$-phenylurea) porphyrins $\left(\mathrm{P}_{1}-\mathrm{P}_{4}\right)$ and their $\mathrm{Mn}$ and $\mathrm{Co}$ complexes ( $\mathrm{MnP}$ and $\mathrm{CoP}$ ) were comparable and in some cases, even superior to previously synthesized porphyrins and metalloporphyrins in terms of the growth inhibitory effects ( $\mathrm{Li}$ et al. 1997; Beirão et al. 2014; Prasanth et al. 2014; Meng et al. 2015; Zoltan et al. 2015).

\section{CONCLUSIONS}

The present work studied the synthesis and characterization of some new 5,10,15-tris(4aminophenyl)-20-( $N, N$-dialkyl/diaryl- $N$ phenylurea) porphyrin ligands $\left(\mathrm{P}_{1}-\mathrm{P}_{4}\right)$ and their $\mathrm{Mn}(\mathrm{III})$ and $\mathrm{Co}$ (II) complexes ( $\mathrm{MnP}, \mathrm{CoP})$ and evaluation of their antibacterial activity against $E$ coli, $P$. aeruginosa, S. aureus, B. subtilis and antifungal activity against $A$. oryzae and $C$. albicans in vitro by agar-disc diffusion method. The peripheral urea derivative substituents in the para position of phenyl ring affected the antibacterial and antifungal activity of these porphyrin ligands. The order of activity for the ligands was $\mathrm{P}_{1}>\mathrm{P}_{2}>\mathrm{P}_{3}$ $>\mathrm{P}_{4}$, which was consistent with the order of their liposolubility. However, $\mathrm{MnP}$ and $\mathrm{CoP}$ complexes showed higher antibacterial and antifungal activities than $\mathrm{P}_{1}-\mathrm{P}_{4}$ ligands and markedly inhibited the growth of most bacteria and fungi tested. The result also showed that the order of activity for the $\mathrm{Mn}(\mathrm{III})$ complexes was $\mathrm{MnP}_{1}>$ $\mathrm{MnP}_{2}>\mathrm{MnP}_{3}>\mathrm{MnP}_{4}$ and for the $\mathrm{Co}$ (II) complexes, it was $\mathrm{CoP}_{1}>\mathrm{CoP}_{2}>\mathrm{CoP}_{3}>\mathrm{CoP}_{4}$. Generally, the $\mathrm{Co}$ (II) complexes virtually exhibited enhanced antibacterial and antifungal activities compared to MnP complexes. This could be related to lower polarity of the $\mathrm{Co}$ (II) complexes (higher lipophilicity), which enhanced the penetration of the complexes into lipid membranes of the microorganism. Among the $\mathrm{Co}(\mathrm{II})$ complexes, $\mathrm{CoP}_{1}$ showed significant inhibitory effects against both Gram-positive $(S$. aureus, B. subtilis) and Gram-negative (E. coli, P. aeruginosa) bacterial and fungus species (A. oryzae, $C$. albicans) and, therefore, could have a potential to be used as drug. Having established antibacterial and antifungal activity of these aminoporphyrins having urea derivative substituents and their metal complexes, the next goal could be to synthesis aminoporphyrins with two or more biological active functions and evaluate their antibacterial, antifungal activity and DNA binding affinities.

\section{ACKNOWLEDGEMENTS}

The authors thank Dr Ebrahimi Mohammadi (University of New South Wales, Australia) who kindly edited the English texts. Also, the partial support of this work by the Yasouj University Research Council is gratefully acknowledged.

\section{REFERENCES}

Adler AD, Longo FR, Finarelli JD, Goldmacher J, Assour J, Korsakoff L. A simplified synthesis for meso-tetraphenylporphine. J Org Chem. 1967; 32(2): 476-476.

Adler AD, Longo FR, Kampas F, Kim J. On the preparation of metalloporphyrins. J Inorg Nucl Chem. 1970; 32(7): 2443-2445.

Babad H, Zeiler AG. The chemistry of phosgene. Chem Rev. 1973; 73(1): 75-91.

Bajju GD, Kundan S, Bhagat M, Gupta D, Kapahi A, Devi G. Synthesis and spectroscopic and biological activities of $\mathrm{Zn}(\mathrm{II})$ porphyrin with oxygen donors. Bioinorg Chem App1. 2014; 2014: Article ID 428121, 1-13.

Banfi S, Caruso E, Buccafurni L, Battini V, Zazzaron S, Barbieri P, et al. Antibacterial activity of tetraarylporphyrin photosensitizers: An in vitro study on Gram negative and Gram positive bacteria. $J$ Photochem Photobiol B. 2006; 85(1): 28-38.

Baron EJ, Chang RS, Howed HD. Medical Microbiology. New York: Wiely Liss. Publication; 1994.

Beirão S, Fernandes S, Coelho J, Faustino MAF, Tomé JPC, Neves MGPMS. Photodynamic inactivation of bacterial and yeast biofilms with a cationic porphyrin. Photochem Photobiol. 2014; 90(6): 1387-1396.

Boulton B, Rozanowska M, Rozanowski B. Retinal photodamage. J Photochem Photobiol B. 2001; 64(23): 144-161.

Chen CT, Hsieh SJ. Synthesis and characterization of push-pull porphyrins. J Chin Chem Soc. 1997; 44(1): 23-31.

Chiller K, Selkin BA, Murakawa GJ. Skin microflora and bacterial infections of the skin. J Investig Dermatol Symp Proc. 2001; 6(3): 170-174.

Chizhova NV, Kumeev RS, Mamardashvili NZ. Synthesis and spectral properties of cobalt(II) and cobalt(III) tetraarylporphyrinates. Russ J Inorg Chem. 2013; 58(6): 740-743. 
Dosselli R, Tampieri C, Ruiz-González R, De Munari S, Ragàs X, Sánchez-García D, et al. Synthesis, characterization, and photoinduced antibacterial activity of porphyrin-type photosensitizers conjugated to the antimicrobial peptide apidaecin 1b. J Med Chem. 2013; 56(3): 1052-1063.

Fish PV, Barta NS, Gary DL, Ryckmans T, Stobie A, Wakenhut F, et al. Derivatives of (3S)-N-(biphenyl-2ylmethyl)pyrrolidin-3-amine as selective noradrenaline reuptake inhibitors: Reducing P-gp mediated efflux by modulation of $\mathrm{H}$-bond acceptor capacity. Bioorg Med Chem Lett. 2008; 18(15): $4355-$ 4359.

Goodrich LE, Roy S, Alp EE, Zhao J, Hu MY, Lehnert N. Electronic structure and biologically relevant reactivity of low-spin $\{\mathrm{FeNO}\}^{8}$ porphyrin model complexes: new insight from a bis-picket Fence porphyrin. Inorg Chem. 2013; 52(13): 7766-7780.

Goren Z, Heeg MJ, Mobashery S. Facile chloride substitution of activated alcohols by triphosgene: application to cephalosporin chemistry. J Org Chem. 1991; 56(25): 7186-7188.

Grzyb JA, Batey RA. Achieving functional group diversity in parallel synthesis: solution-phase synthesis of a library of ureas, carbamates, thiocarbamates, and amides using carbamoylimidazolium salts. Tetrahedron Lett. 2008; 49(36): 5279-5282.

Gumaste VK, Deshmukh ARAS. One-pot preparation of dialkylcarbamoyl azides from tertiary amines using triphosgene and sodium azide. Tetrahedron Lett. 2004; 45(35): 6571-6573.

Hamdach A, El Hadrami EM, Gil S, Zaragozá RJ, Zaballos-García E, Sepúlveda-Arques J. Reactivity difference between diphosgene and phosgene in reaction with (2,3-anti)-3-amino-1,2-diols, Tetrahedron. 2006; 62(26): 6392-6397.

Hood HP, Murdock HR. Superpalite. J Phys Chem. 1919; 23(7): 498-512.

Indu MN, Hatha AAM, Abirosh C, Harsha U, Vivekanandan G. Antimicrobial activity of some of the south-Indian spices against serotypes of Escherichia coli, Salmonella, Listeria monocytogenes and Aeromonas hydrophila. Braz J Microbiol. 2006; 37: 153-158.

Johnson CK. A new synthesis of 2-chloroalkyl isocyanates. J Org Chem. 1967; 32(5): 1508-1510.

Kamisaki H, Yasui Y, Takemoto Y. Pd-catalyzed intramolecular amidation of 2-(buta-1,3dienyl)phenylcarbamoyl chloride: a concise synthesis of spiro[indoline-3,3'-pyrrolidine]. Tetrahedron Lett. 2009; 50(21): 2589-2592.

Karimipour G, Ghaedi M, Behfar M, Andikaey Z, Kowkabi S, Orojloo AH. Synthesis and application of new porphyrin derivatives for preparation of copper selective electrodes: influence of carbon nanotube on their responses. IEEE Sens J. 2012; 12(8): 26382647.
Karimipour G, Karami B, Montazerozohori M, Zakavi S. Oxidative decarboxylation of carboxylic acids with tetrabutylammonium periodate catalyzed by manganese (III) meso-tetraarylporphyrins: effect of metals, meso-substituents, and anionic axial ligands. Chin J Catal. 2007; 28(11): 940-946.

Karimipour G, Rezaei M, Ashouri D. Zeolite encapsulated Fe-porphyrin for catalytic oxidation with iodobenzene diacetate $\left(\mathrm{PhI}(\mathrm{OAc})_{2}\right)$. J Mex Chem Soc. 2013; 57(4): 276-282.

Katsunori Y, Yamanishi K, Yairi T, Suzuki K, Kondo M. Biomimic $\mathrm{O}_{2}$ activation hydroxylates a mesocarbon of the porphyrin ring regioselectively under mild conditions. Chem Commun. 2013; 49(81): 92969298.

Kurita K, Matsumura T, Iwakura Y. Trichloromethyl chloroformate. Reaction with amines, amino acids, and amino alcohols. J Org Chem. 1976; 41(11): 2070-2071.

Lauher JW, Ibers JA. Stereochemistry of cobalt porphyrins. II. Characterization and structure of meso-tetraphenylporphinatobis (imidazole) cobalt (III) acetate monohydrate monochloroformate, $\left[\mathrm{Co}(\mathrm{Im})_{2}(\mathrm{TPP})\right][\mathrm{OAc}] \cdot \mathrm{H}_{2} \mathrm{O} \cdot \mathrm{CHCl}_{3}$. J Am Chem Soc. 1974; 96(14): 4447-4452.

Li H, Fedorova OS, Grachev AN, Trumble WR, Bohach GA, Czuchajowski L. A series of meso-tris N-methyl-pyridiniumyl)-(4-alkylamidophenyl) porphyrins: synthesis, interaction with DNA and antibacterial activity. Biochim Biophys Acta. 1997; 1354(3): 252-260.

Maisch T, Szeimies RM, Jori G, Abels C. Antibacterial photodynamic therapy in dermatology. Photochem Photobiol Sci. 2004; 3(10): 907-917.

Marcos IS, Beneitez A, Moro RF, Basabe P, Diez D, Urones JG. Lateral lithiation in terpenes: synthesis of (+)-ferruginol and (+)-sugiol. Tetrahedron. 2010; 66(39): 7773-7780.

Marrs TC, Maynard RL, Sidell FR. Chemical Warfare Agents. Toxicology and Treatment. Chichester: J Wiley and Son; 1996, 185p.

Meisel P, Kocher T. Photodynamic therapy for periodontal diseases: State of the art. J Photochem Photobiol B. 2005; 79(2): 159-170.

Meng S, Xu Z, Hong G, Zhao L, Zhao Z, Guo J, et al. Synthesis, characterization and in vitro photodynamic antimicrobial activity of basic amino acid-porphyrin conjugates. Eur J Med Chem. 2015; 92: 35-48.

Michael FP, Emil FP, Thomas CB. Study of (tetraphenylporphinato) manganese(III)-catalyzed epoxidation and demethylation using p-cyano-N,Ndimethylaniline $\mathrm{N}$-oxide as oxygen donor in a homogeneous system. Kinetics, radiochemical ligation studies, and reaction mechanism for a model of cytochrome P-450. J Am Chem Soc. 1984; 106(11): 3277-3285. 
Mohajer D, Karimipour G, Bagherzadeh M. Reactivity studies of biomimetic catalytic epoxidation of alkenes with tetrabutylammonium periodate in the presence of various manganese porphyrins and nitrogen donors: significant axial ligand $\pi$-bonding effects. New J Chem. 2004; 28; 740-747.

Montel F, Lamberth C, Jung PMJ. First synthesis of 7amido-[1,2,4]triazolo[1,5-a]pyrimidines using halogen-metal exchange. Tetrahedron. 2008; 64(27): 6372-6376.

Murray PR, Baron EJ, Faller MAP, Tenover FC, Yken RH. Manual of clinical microbiology. Washington: 7th ed, Asapress; 1991.

National Committee for Clinical Laboratory Standards, NCCLS Approved Standard M27-A.

Wayne Pa. Pennsylvania; 1997.

Nolan AM, Amberger BK, Esselman BJ, Thimmakondu VS, Stanton JF, Woods RC, et al. Carbonyl diazide, $\mathrm{OC}\left(\mathrm{N}_{3}\right)_{2}$ : synthesis, purification, and IR spectrum. Inorg Chem. 2012; 51(18): 9846-9851.

Nowak-Król A, Gryko DT. Oxidative aromatic coupling of meso-arylamino-porphyrins. Org Lett. 2013; 15(22): 5618-5621.

Orlandi VT, Caruso E, Banfi S, Barbieri P. Effect of organic matter on the in vitro photoeradication of pseudomonas aeruginosa by means of a cationic tetraaryl-porphyrin. Photochem Photobiol. 2012; 88(3): 557-564.

Orlandi VT, Caruso E, Tettamanti G, Banfi S, Barbieri P. Photoinduced antibacterial activity of two dicationic 5,15-diarylporphyrins. $J$ Photochem Photobiol B. 2013; 127: 123-132.

Overton CE. Studien über die Narkose zugleich ein Beitrag zur allgemeinen Pharmakologie. Gustav Fischer. Jena: Switzerland; 1901.

Prasanth CS, Karunakaran SC, Paul AK, Kussovski V, Mantareva V, Ramaiah D, et al. Antimicrobial photodynamic efficiency of novel cationic porphyrins towards periodontal gram-positive and gram-negative pathogenic bacteria. Photochem Photobiol. 2014; 90(3): 628-640.

Ramsperger HC, Waddington G. The kinetics of the thermal decomposition of trichloromethyl chloroformate. J Am Chem Soc. 1933; 55(1): 214220.
Ryan TA, Ryan C, Seddon EA, Seddon KR. Phosgene and Related Carbonyl Halides. Amsterdam: Elsevier; 1996, 223p.

Satyasheel S, Mahendra, N. Synthesis of mesosubstituted dihydro-1,3-oxazinoporphyrins. Beilstein J Org Chem. 2013; 9: 496-502.

Skorna G, Ugi I. Isocyanide synthesis with diphosgene. Angew Chem Int Ed Engl. 1977; 16(4): 259-260.

Tabatabaeian K, Mahmoodi NO, Najafi Yasouri, Amirrahmat R. Synthesis and investigation of biological activities of a new $\alpha$-methylene- $\gamma$ butyrolactone using cobaloxime catalyzed radical cyclization. J Chem Pharm Res. 2013; 5(4): 8-12.

Tilley JN, Sayigh AAR. Pyrolysis of N-t-Butyl-Nalkylcarbamoyl chlorides. A new synthesis of isocyanates. J Org Chem. 1963; 28(8): 2076-2079.

Tweedy BG. Plant extracts with metal ions as potential antimicrobial agents. Phytopathology. 1964; 55: 910917.

Zahid HC, Sajjad HS, Moulay HY, Taibi BH. Metal based biologically active compounds: Design, synthesis, and antibacterial/antifungal/cytotoxic properties of triazole-derived Schiff bases and their oxovanadium(IV) complexes. Eur J Med Chem. 2010; 45(7): 2739-2747.

Lemire JA, Harrison JJ, Turner RJ.Antimicrobial activity of metals: mechanisms, molecular targets and applications. Nature Rev Microbiol. 2013; 11: 371384.

Zare H, Ghanbari MM, Jamali M, Aboodi A. A novel and efficient strategy for the synthesis of various carbamates using carbamoyl chlorides under solventfree and grinding conditions using microwave irradiation. Chin Chem Lett. 2012; 23(8): 883-886.

Zoltan T, Vargas F, López V, Chávez V, Rivas C, Ramírez ÁH. Influence of charge and metal coordination of meso-substituted porphyrins on bacterial photoinactivation. Spectrochim Acta Part A Mol Biomol Spectrosc. 2015; 135: 747-756.

Received: January 14 2015; Accepted: April 02, 2015 